\title{
A FOURFOLD VIEW OF THE LORD'S SUPPER.
}

REV. C. E. DOBBS, D. D., MARIETTA, GA.

About the table of our Lord have been joined the fiercest battles of theological debate. Especially is this true of postReformation controversy. Before Luther there was discussion, of course, concerning the nature of the sacred rite; but ecclesiastical annals do not show any such intensity of feeling as has been manifested in the controversies since the great reformer began his work. To-day the one overshadowing differentiating dogma separating the Catholic and the Protestant is not so much that which affirms the spiritual supremacy of the Roman pontiff as it is that which enfolds the Romish doctrine of the Mass. It is in discussing that one subject that the tension is most severely strained. Naught else can so stir to its very depths the enthusiasm of the worshipper at Rome's altar as that supreme act of her ritual in which the consecrated Host is uplifted for the adoration of the faithful. And in her sight there can be no more heinous display of sinful heresy than that temerity which ventures to question the reality of that continuous miracle wrought through the words of the priestly consecration of the sacred elements. Thus to the sincere Catholic the "Holy Mass" is not only the highest form of Christian worship; it is the one distinguishing mark of his beloved Mother Church, wanting which all others are wandering in the sin and hopelessness of error and schism.

\section{PERPETUITY OF THE SUPPER.}

It is here assumed that Jesus instituted the supper to be observed as a memorial rite till he come the "second time," apart from sin, to them that wait for him, unto salvation." Not that this is universally admitted, for it is not. Of course, 
every one knows that the Society of Friends, commonly called "Quakers," rejects the supper. Yet few readers, perhaps, have seen the officiel ples for that rejection. As it is my purpose, as far as possible, to give authoritative utterances in this discussion, I quote from the Friends' Confession:

"The communion of the body and blood of Christ is inward and spiritual, which is the participation of his flesh and blood, by which the inward man is daily nourished in the hearts of those in whom Christ dwells; of which things the breaking of bread by Christ was a figure, which they used in the Church for a time, who had received the substance, for the cause of the weak; even as 'abstaining from things strangled and from blood; the washing one another's feet, and the anointing of the sick with oil, all which are commanded with no less authority and solmenity than the former; yet seeing they are but shadows of better things, they cease in such as have the substance..'"

Dr. Thomas Chase, president of Haverford College, in the Schaff-Herzog Encyclopædia says: "Their belief in the spirituality of Christianity has led them to the disuse of the outward rites of baptism and the Lord's supper. *** They do not find, in the texts ordinarily understood as establishing these rites, any indication of such intention, and regard the rites themselves as inconsistent with the whole spirit of Christianity, in which types have given place to the substance." It is scarcely within the purview of this paper, even were it necessary, to show the irrelevancy of the argument advanced by the Friends. Certainly every thoughtful reader must see that the holy rite in question rests on a very different basis, for example, from that concerning the "abstaining from things strangled."

Others than the Friends have failed to see the permanent obligation to observe the supper. Some Universalists and Unitarians have argued that, even admitting the intention of Jesus to found a rite, it "terminated with the assigned limitation," "till he come," which "coming" they interpret of the overthrow of the Jewish state by Titus in A. D. 70. Others still, with a freedom verging closely on irreverence for our Lord, say: "We must associate Christ's touching request to be remembered rather with a personal affection and expectation 
of reunion than with a far-reaching intention to establish a ritual for all time. It was the word of a brother, not the decree of a church-creator; it was the cry of yearning love, not the command of authority; it was rather a token of affection for them than the establishment of a rite for us." This is enforced by the bold assumption: "It is, perhaps, an open question whether he and they alike believed in the speedy literal ending of the world, but it is hardly an open question whether they dwelt almost exclusively on their personal relations with one another." Such reasoning may answer the demands of a rationalistic faith, rather non-faith, but it will fail to satisfy the heart of one who reveres and trusts the Lord Jesus as the divine Saviour. Certainly they to whom the primitive word of our Lord was given did not so understand his solemn act and purpose. With practical unanimity his followers have accepted that word as instituting a holy memorial rite of permanent obligation.

The supper did not long survive in its primitive purity of intention and celebration. Scarcely do we close the New Testament and pass into the earliest Christian literature when we see evidence of error gathering about the rite. But not with those early misconceptions is it the present purpose to deal, only as they incidentally appear in the discussions of a later day. Rather let us come at once to consider the fourfold view of the supper as it appears in modern controversy. For simplicity of presentation we may say that there are four general views of the rite, though confessedly these views quite frequently overlap and interlace each other. Still, for all practical purposes, they are sufficiently differentiated.

THE ROMAN CATHOLIC VIEW.

The view presented under this head is held also by the Greek and other ritualistic churches of the East. Frequently Catholics complain, and, alas, too often not unjustly, that Protestants misunderstand and misrepresent their teaching. It shall be the present aim to let them speak for themselves in their own words from their authorized symbols. Commonly it is said 
that Catholics believe in "transubstantiation." So they do, but that word merely expresses one phase of their faith, and that only the mode by which the one great mystery of the altar is accomplished. Let us take a more comprehensive phrase, namely, the Real Presence. Let the definition be their own. Their doctrine is officially given in the "Canons and Decrees of the Council of Trent" (A. D. 1545-1563). I quote:

"In the Eucharist are contained truly, really and substantially, the body and blood, together with the soul and divinity of our Lord Jesus Christ."

This deliverance has official explanation in Deharbe's "Shorter Catechism of the Catholic Religion," issued under the imprimatur of Cardinal McCloskey, Archbishop of New York. Here is the answer to question 328:

"The Holy Eucharist is the true Body and the true Blood of our Lord Jesus Christ, who is really and substantially present under the appearances of bread and wine for the nourishment oi our souls."

To make the meaning yet clearer, it is asked:

" 335 . Is there, then, no bread and wine on the altar after the consecration?"

"No; there is on the altar the true Body and the true Blood of Jesus Christ under the appearances of bread and wine."

It is further taught, in accord with canon three of the Council of Trent that when "the priest breaks or divides the sacred Host, he does not break the body of Christ," but that the "entire body of Christ is present in each part in a mysterious manner." What a lot of little bodies, to be sure! In Bossuet's "Exposition of the Doctrines of the Catholic Church" it is said that "in the Eucharist the Christian eats effectually of the flesh of the holy sacrifice"; "the body of Jesus Christ, the true victim offered up for sin," is "really eaten by the faithful." Shrink as we may from literalism so bald, the devout Catholic sees nothing gross or absurd in this teaching. Bossuet argues enrnestly that all this is involved in the very words of institution-"this is my body-this is my blood." The utterance of the sacred words by the priest at the altar marks the precise moment of time when the "bread and wine are mirac- 
lously converted into the real body and blood of our Redeemer." This change they express by the term "transubstantiation." According to John Henry Blunt, the eminent Church of England writer, the word transubstantiation was first used in the seventh century, and was not officially designative of the supposed miracle till the Council of Trent employed it in that sense. The "adoration of the Host" is the logical consequent of the miracle. Hence at the elevation of the sacred elements by the priest after the consecration every pious Catholic falls upon his knees in solemn awe and reverent worshipas positive an act of idolatry as ever pagan temple witnessed!

The mystery of transubstantiation once admitted, and what Catholics call the "Sacrifice of the Mass" is credible. Thus they hold that "in every celebration of the sacrament there is the perpetual sacrifice of the New Law, in which Christ, under the appearances of bread and wine, offers himself to his heavenly Father by the hands of the priest, as $\mathrm{He}$ once offered Himself on the cross." It is declared that "the Sacrifice of the Mass is essentially the same as the Sacrifice of the Cross, only that on the Cross $\mathrm{He}$ offered Himself in a bloody manner, but in the Mass in an unbloody manner." And this "unbloody sacrifice" is supposed to "propitiate God" and to "dispose the divine goodness to be the more kind and propitious to us."

Such is the view of the holy rite entertained by the majority of the professing Christian world to-day. I said that the Greek Church held it in common with the Catholics. The "Catechism of the Holy Eastern Church" affirms:

"The Eucharist, or Communion, is a mystery in which the believer, under the form of bread, receives the body itself of Christ; and under the form of wine, the blood itself of Christ, for the remission of sin, and unto eternal life." "Consequently every true Christian ought to be persuaded that in this sublime rnystery he does not receive simple bread and wine; but that, under the form of hallowed bread, he receives the true body itself of Christ, which was offered a sacrifice upon the cross."

In this connection it should be remembered that the Greek Church uses the word "mystery" as the Catholics use the word "sacrament," which is defined to be a "visible sign instituted by 
Jesus Christ whereby invisible grace and sanctification are communicated to our souls." This is certainly the ecclesiastical meaning of "sacrament." Historically in classical Latin "sacramentum" meant the sacred military oath by which soldiers were bound to allegiance and obedience. The early ecclesiastical use of the word had reference most frequently to baptism, doubtless from the idea of enrolling a convert under Christ's banner by a vow of obedience as the soldier was enrolled by his "sacramentum." Tertullian so uses the term. He calls baptism the "sacramentum aquæ"- "sacramentum lavacri""sacramentum fidei." He also uses the phrase "sacramentum Eucharistæ," showing that the term had already been extended in its use to something more than the idea of enrollment on beginning service as a Christian soldier, though there still inhered in the term the thought of a vow or confession. By the time of Jerome and Augustine the ecclesiastical use of the word in its present sense seems to have become settled. The "sacrament" has been almost unanimously held to be not only a sign, but also the means whereby, and the medium through which, grace is conferred. It would be well for evangelical believers to discard the word when referring to the gospel rites. They are signs, but surely not channels, of grace. Leave the word to those who believe that salvation is secured by ritual.

THE LUTHERAN VIEW.

It is difficult to state the Lutheran view with exactness and at the same time clearly distinguish it from the Catholic position. Bossuet quotes Luther as having said: "I should have wished to have denied the real presence of Christ in the Eucharist, in order to incommode the papists; but so clear and so strong are the words of scripture which establish it that, in spite of my inclination, and although I strained every nerve to do so, yet never could I persuade myself to adopt the bold expedient." Bossuet gives no reference whereby the supposed quotation can be verified, and surely it was not a very politic confession for a controversialist to make in the face of an opponent. There can be little question that the great reformer 
never could wholly break with the traditional view in which the church had reared him. The authoritative teaching of the Lutheran Church is that given in the Augsburg Confession, issued A. D. 1530:

"The true body and blood of Christ are truly present under the form of bread and wine, and are there communicated to and received by those that eat in the Lord's Supper."

Dr. Von Burger, an eminent Lutheran divine, says: "Our Iord called what he gave his disciples his body and his blood; and no circumstance leads us to suppose they were anything else. * * * But the Lutheran Church rejects transubstantiation, while insisting that the body and blood of Christ aro mysteriously and supernaturally united with the bread and wine, so that they are received when the latter are. *** This union of the earthly and the heavenly elements is essential to the sacrament." This same divine further argues that "nothing depends upon the spiritual condition of the recipient," but in every instance of partaking the communicant, good or bad, swallows the ever present flesh and blood of Jesus! Another eminent Lutheran, Dr. C. F. Luthardt, argues that "the Lord's Supper is not a sacrifice, as the Romish dogma teaches, but a feast." At the same time he says: "What the disciples take and eat is his body. It is not merely bread. It is not merely an image and sign and pledge of his body. * * * Invisibly present and working in a mysterious way, th $\theta$ Lord feeds us with his body and blood."

Luther, instead of "transubstantiation," chose to express his view of the real presence by the word "consubstantiation." He argued that according to the Romish view the bread and wine are by the consecration transformed into the flesh and blood of Christ; while, according to his teaching, "the elements remain bread and wine, though, after consecration, the real flesh and blood of Christ co-exist in and with it." This illustration occurs in Luther's famous letter to Henry VIII. In view of these utterances one is almost obliged to conclude with Bossuet that "the Lutherans continue as firmly attached to the belief in the Real Presence as is the Catholic Church itself." 
Closely allied to both the Catholic and Lutheran views is that known as the "High Anglican View." In the first English Prayer Book-that of King Edward VI., issued in 1549-I find very clearly stated this view:

"Wherefore our duty is to come to these holy Mysteries with most hearty thanks to be given to Almighty God for his infinite mercy and benefits given and bestowed upon us, his unworthy servants, for whom he has not only given his body to Death, and shed his Blood, but also doth vouchsafe, in a Sacrament and Mystery, to give us his said Body and Blood to feed upon spiritually. *** And here we offer and present unto thee, $O$ Lord, ourself, our souls and bodies, to be a reasonable, holy, and lively sacrifice unto thee; humbly beseeching thee that whosoever shall be partakers of this holy Communion may worthily receive the most precious Body and Blood of thy son Jesus Christ."

In the "Order for Communion" issued in 1548 it is said in a rubric: "And every one of the said consecrated Breads shall be broken in two pieces, at the least, or more, by the discretion of the Minister, and so distributed. And men must not think less to be received in part than in the whole, but in each of them the whole Body of our Saviour Jesus Christ." I quote from the reprinted edition by Dr. Morgan Dix. In the Catochism in the present English prayer book are these questions and answers:

"What is the outward part or sign of the Lord's Supper?"

"Bread and wine, which the Lord hath commanded to be received."

"What is the inward part, or thing, signified?"

"The Body and Blood of Christ, which are verily and indeed taken and received by the faithful in the Lord's Supper."

"What are the benefits whereof we are partakers thereby?"

"The strengthening and refreshing of our souls by the Body and Blood of Christ, as our bodies are by the Bread and Wine."

In the Catechism as it appears in the American prayer book the words "verily and indeed" are modified into "spiritually." The English ecclesiastic quoted, John Henry Blunt, in his many works has elaborately set forth this view. For example, 
he says: "The bread and wine become by consecration really and sacramentally (though in an inconceivable manner, which cannot be explained by earthly similitudes or illustrations) the body and blood of our Lord." He presses this doctrine of the real presence, in contradistinction to that of the figurative presence, according to which the elements are "only memorials of Christ's body and blood"; and to that of the virtual presence, "as if our Lord only bestowed in the Eucharist the graces and blessings derived from his atoning sacrifice," and "not his own true and real self." $\mathrm{He}$ contends:

"That the body and blood of Christ exist in those elements is as much the belief of the English Church as of the Latin and Greek Churches - the divine words uttered at the first institution being effective throughout all ages of the Church, changing ineffably the creatures of bread and wine into the heavenly food of Christ's most precious body and blood."

In contrast with this bold position is the well-known fact that in the twenty-eighth of her "articles of religion" the Church of England declares: "Transubstantiation (or the change of the substance of Bread and Wine) in the Supper of the Lord, cannot be proved by holy writ; but is repugnant to the plain words of Scripture, overthroweth the nature of a Sacrament and hath given occasion to many superstitions." It is further therein declared: "The Body of Christ is given, taken and eaten in the Supper, only after an heavenly and spiritual manner. And the means whereby the body of Christ is received and eaten in the Supper is Faith." In his "Exposition of the Thirty-nine Articles," Bishop Burnet-gives a very interesting history of the formation of this particular protest against the Romish dogma, which history shows it was the purpose of the early English reformers to reject the idea of a "real and bodily presence of Christ's flesh and blood in the Sacrament." He spends much time in an argument against the Romish view, and concludes that "if this Sacrament had been that mysterious and inconceivable thing which it has been since believed to be, we cannot imagine but that the Acts of the Apostles, and their Epistles, should have contained fuller explanations about it." But Burnet wrote in the day of good William 
and Mary, and certainly does not adequately represent the faith of later Episcopalians. It is not too much to say that in both the Anglican and American branches of that communion all shades of opinion are to be found, varying from extreme Romanism to the very loosest Zwinglianism. Probably the twenty-seventh of the "Reformed Episcopal Articles of Roligion" correctly voices the opinion of the mass of evangelical Episcopalians:

"The Supper of our Lord is a memorial of our redemption by Christ's death, for thereby do we show forth the Lord's death till he come. It is also a symbol of the soul's feeding upon Christ. And it is a sign of the communion that we should have with one another."

\section{THE Calvinian VIEW.}

This is otherwise known as the "Reformed View" in contradistinction to the Lutheran statement. The First Helvetic Confession (A. D. 1536) declared that "the bread and wine are holy, true symbols, through which the Lord offers and presents the true communion of the body and blood of Christ for the feeding and nourishing of the spiritual and eternal life." The Reformed branches of Protestantism followed Calvin rather than Luther, though it must be confessed Calvin sometimes appears to be clear over on the Lutheran ground. In his "Institutes" (IV., chapters 17 and 18), he elaborately discusses the question. Let me quote almost at random:

"As in baptism God regenerates us and makes us his children by adoption, so he acts toward us as a provident father of a family in constantly supplying us with food to sustain and preserve us in that life to which he has begotten us by his word. Now the only food of our souls is Christ."

"Though it appears incredible for the flesh of Christ from such an immense local distance (i. e., from heaven) to reach us, so as to become our food, we should remember how much the secret power of the Holy Spirit transcends all our senses."

"Therefore, if by the breaking of the bread the Lord truly represents the participation of his body, it ought not to be doubted that he truly presents and communicates it." 
"If it be true that the visible sign is given to us to seal the donation of the invisible substance, we ought to entertain a confident assurance that in receiving the symbol of his body we at the same time truly receive the body itself."

As a parallel to Luther's illustration of the heated iron bar, Calvin has this: "For, if we behold the sun darting his rays and transmitting his substance, as it were, in them, to generate, to nourish, and mature the roots of earth, why should the irradiation of the Spirit be less effectual to convey to us the communication of his body and blood?"

The Presbyterian Confession of Faith echoes Calvin:

"Worthy receivers outwardly partaking of the visible elements in this sacrament, do then also inwardly by faith, really and indeed, yet not carnally and corporally, but spiritually, receive and feed upon Christ crucified, and all benefits of his death; the body and blood of Christ being then not carnally or corporally in, with, or under the bread and wine; yet as really, but spiritually, present to the faith of believers in that ordinance, as the elements themselves are, to their outward senses."

It is possible that our good Presbyterians may have some idea of what this deliverance means, but for the mass of us it must be referred to the traditional "Philadelphia lawyer" for explanation.

Herzog, in presenting the Reformed, or Calvinian, view. takes occasion to remark that "the Lutherans are not yet completely emancipated from Romanism"-a compliment which might with entire justice be returned by the Lutherans! This, at least, may be said: All the views so far considered are founded on, and pervaded by, the sacramental idea that the grace promised is not only symbolized and offered, but really exhibited and conferred in the rite." Indeed it is expressly taught in the Shorter Catechism that "worthy receivers are, not after a corporal and carnal manner, but by faith, made partakers of his body and blood, with all its benefits, to their spiritual nourishment and growth in grace." The supper is thus affirmed to be more than a memorial, a sign; it is really a "channel and means of grace." This is why even the most 
evangelical communicants approach the "altar" with a sense of awe and receive the consecrated elements believing that spiritual benefits are therein and thereby imparted.

\section{THE MEMORIAL VIEW.}

The memorial view is that commonly known as the Zwinglian view of the supper. In the opinion of this great reformer "sacraments are mere signs of initiation and of a pledge to continue in the outward society; they confer no grace, they minister no faith, they do not free the conscience; they are not even pledges of grace; they are tokens rather to the Church of the disposition of the recipient than to the recipient of his sonship in Christ." So Blunt summarizes the system. Zwingli's view of the supper is that almost universally held among Baptists. As one of our greatest and best, Dr. John A. Broadus, says: "The bread is simply appointed as the symbol or memento which we take in remembrance of the Saviour's body. Tho natural effect of such a memento or symbol in vividly reminding of the Saviour, and kindling grateful affection toward him, is blessed to the devout participant. But the blessing thus received is not essentially different in kind from other spiritual blessings, or associated by mere divine appointment with this particular means of grace." Most Baptist exponents could be quoted to the same tenor.

We should view the Supper, not as a "sacrament," but a simple commemorative rite. The Passover was a memorial of deliverance from the avenging death angel, and of the passing of Israel out of Egypt; and, year after year, as the pious Jew observed it, he was reminded of that marvellous interposition of Jehovah in behalf of his forefathers. The Lord's supper was instituted by our Lord to be observed by his disciples as a memorial of his atoning death. This is all; nor should we read more into the sacred rite. As such it stands before the world as one of the ordained monumental witnesses to Christianity. In this its sublime significance consists. As oft as we eat the bread and dring the cup we show forth our holy faith, and present a striking plea for the historic Christ and his 
gospel of grace. "The celebration of the holy Eucharist," as Brooke Foss Westcott has well written, "is absolutely unintelligible without faith in a risen Saviour; for the rite was not a memorial of death simply, but of death conquered by life." Uninterruptedly from the beginning this witnessing rite has come down the centuries. Tracing it backward, we reach thn very presence of our Lord and the fundamental facts memorialized. It began in the belief in the risen Christ, and that belief was born under circumstances precluding mistakes as to the reality of the events in question. In this view the Supper is a beautiful and singularly suggestive rite. Transform it into a saving sacrament and its glory fades; thenceforth it becomes but the instrument of superstitious manipulation; a snare and delusion to them who adore and tremblingly trust its supposed grace. 